\title{
Urgensi Pengawasan Preventif terhadap Qanun No. 3 Tahun 2013 tentang Bendera dan Lambang Aceh
}

\author{
Melisa Fitria Dini \\ Fakultas Hukum Universitas Islam Indonesia \\ Jl. Tamansiswa No. 158 Yogyakarta \\ melisafitdiin@gmail.com
}

\begin{abstract}
This research discusses: first, the authority of government evaluation on Qanunof Aceh flag and symbol, and second, the urgency of preventive inspection to Qanun No. 3 of 2013. The method used in this study was normative juridical using regulations of law and conceptual approaches. The result of research shows that: first, the government is not authorized anymore to cancel Qanunof Aceh flag and symbol since the discussion period is outdated as stated in Article 145 of Law No. 32 of 2004 on the Regional Government. Second, the urgency of preventive inspection to Qanun No. 3 of 2014 on Aceh flag and symbol by the government is necessary to guarantee the legal supremacy and to maintain the unity of the Republic of Indonesia.
\end{abstract}

Key words: Qanun, regional regulation inspection, Aceh

\begin{abstract}
Abstrak
Penelitian ini mengemukakan permasalahan: pertama, kewenangan evaluasi Qanun Bendera dan Lambang Aceh yang dilakukan oleh Pemerintah. Kedua, urgensi pengawasan preventif terhadap Qanun No. 3 Tahun 2013. Metode penelitian yang digunakan dalam penelitian ini adalah yuridis normatif, dengan menggunakan pendekatan perundang-undangan dan pendekatan konsep. Hasil penelitian menyimpulkan bahwa: pertama, Pemerintah sudah tidak berwenang untuk membatalkan Qanun Bendera dan Lambang Aceh karena masa waktu pembahasan sudah daluwarsa sebagaimana ketentuan dalam Pasal 145 UU No. 32 Tahun 2004 tentang Pemerintahan Daerah. Kedua, urgensi pengawasan preventif tehadap Qanun No. 3 Tahun 2014 tentang Bendera dan Lambang Aceh oleh Pemerintah sangat diperlukan untuk menjamin supremasi hukum dan memelihara persatuan Negara Kesatuan Republik Indonesia (NKRI).
\end{abstract}

Kata kunci: Qanun, pengawasan perda, Aceh 


\section{Pendahuluan}

Otonomi daerah telah membuka ruang bagi daerah untuk dapat mengatur dan mengurus kepentingan daerah. Daerah memiliki kewenangan menetapkan peraturan daerah untuk menjalankan pemerintahan. Daerah otonom sebagai satuan pemerintahan mandiri yang memiliki kewenangan atributif, berwenang membuat peraturan-peraturan untuk menyelenggarakan rumah tangganya. Wewenang mengatur ini ada pada Pemerintah Daerah (pejabat administrasi negara) dan Dewan Perwakilan Rakyat Daerah (DPRD) sebagai pemegang fungsi legislasi di daerah. Perda merupakan pelaksanaan fungsi legislasi DPRD. ${ }^{1}$

Sebelum otonomi diimplementasikan pada 2001, persoalan Bendera di Aceh sudah bergolak sebelum perundingan Helsinki terjadi. Isu yang marak diperdebatkan menyangkut persoalan Gerakan Aceh Merdeka (GAM) yang menuntut adanya partai politik lokal, lagu, dan bendera sendiri. Namun, pihak Pemerintah RI berkilah bahwa lagu kebangsaan dan bendera nasional hanya ada di tingkat pusat. $^{2}$

Sejak kemunculannya, Qanun Aceh No. 3 Tahun 2013, yang ditetapkan oleh Pemerintah Provinsi Aceh sebagai bendera dan lambang provinsi pada 25 Maret 2012 lalu, telah banyak menuai kontroversi. Qanun tersebut disorot tajam karena memiliki model serupa dengan bendera yang dulu dipakai oleh GAM. ${ }^{3}$ Menurut Kepala Biro Hukum Sekretariat Daerah Aceh, Edrian, ${ }^{4}$ bendera dan lambang Aceh ini merupakan tindak lanjut dari nota kesepahaman damai (MoU) Helsinki 2005 antara Pemerintah Indonesia dengan GAM. Seperti yang telah tercantum dalam artikel 1.1.5, MoU Helsinki antara Pemerintah RI dengan GAM: "Aceh has the right to use regional symbols including a flag, a crest and a hymn."

Walaupun sebenarnya Pemerintah telah memberikan kebebasan kepada daerah untuk dapat menentukan bendera dan lambang daerah, khususnya Pemerintah Aceh

\footnotetext{
${ }^{1}$ Bagir Manan, Menyongsong Fajar Otonomi Daerah, PSH FH UII, Yogyakarta, 2001, hlm. 70.

${ }^{2}$ Moch. Nurhasim, Konflik dan Integrasi Politik GAM: Kajian tentang Konsensus Normatif antara RI-GAM dalam Perundingan Helsinki, Pustaka Pelajar dan PSP LIPI, Yogyakarta, 2008, hlm. 170.

${ }^{3}$ http://www.atjehcyber.net/2013/04/purnomo-sebut-ada-motif-lain-di-balik.html, diakses tgl. 22 April 2013.

${ }^{4}$ Dalam Qanun Bendera dan Lambang Aceh ditetapkan, bendera Aceh berbentuk segi empat persegi panjang dengan ukuran lebar 2/3 dari panjang, 2 buah garis lurus putih di bagian atas, 2 buah garis lurus putih di bagian bawah, 1 garis hitam di bagian atas, 1 garis hitam di bagian bawah. Pada bagian tengah bendera terdapat gambar bulan bintang dengan warna dasar merah, putih, dan hitam. Untuk lambang akan terdiri atas gambar singa, buraq, rencong, gliwang, perisai, rangkaian bunga, daun padi, jangkar, huruf ta tulisan Arab, kemudi dan bulan bintang dengan semboyan Hudep Beu Sare Mate Beu Sajan.http://regional.kompas.com/read/2013/03/25/20062356/ Bendera.GAM.Resmi.Berlaku.di.Aceh, diakses 23 April 2013.
} 
dapat menentukan dan menetapkan bendera daerah Aceh sebagai lambang keistimewaan dan kekhususan ${ }^{5}$, bukan sebagai lambang kedaulatan. ${ }^{6}$ Ketentuan ini jelas mengakui hak Aceh untuk mempunyai bendera daerah. Menurut Pasal 1 angka 4 PP No. 77 Tahun 2007 tentang Lambang Daerah, Lambang Daerah adalah panji kebesaran dan simbol kultural bagi masyarakat daerah yang mencerminkan kekhasan daerah dalam Negara Kesatuan Republik Indonesia (NKRI). Bendera daerah sebagai lambang daerah merupakan simbol kultural yang menyatukan masyarakat di daerah. Namun, bendera daerah yang diatur di dalam Qanun No. 3 Tahun 2013 ternyata mirip dengan bendera dari suatu kelompok gerakan separatis Aceh, yakni GAM.

Selain itu, beberapa kabupaten di Aceh, menolak penggunaan bendera yang mirip dengan bendera GAM itu sebagai bendera daerah. Pasal 6 ayat (4) PP Lambang Daerah menyatakan: desain logo dan bendera tidak boleh mempunyai persamaan pada pokoknya atau keseluruhannya dengan desain logo dan bendera organisasi terlarang atau organisasi/perkumpulan/lembaga/gerakan separatis dalam NKRI. Tidak semua masyarakat Aceh sepakat mengenai pemberlakuan Qanun bendera ini, misalnya Organisasi Front Pembela Tanah Air (F-PETA) Kabupaten Aceh Barat menolak keberadaan Qanun bendera Aceh ini. Mereka meminta Presiden SBY untuk membatalkan Qanun No. 3 Tahun 2013 tentang Bendera dan Lambang Aceh dengan alasan bahwa tidak semua rakyat Aceh sepakat dengan penggunaan bendera GAM menjadi bendera daerah. ${ }^{7}$

Menurut Menhan Purnomo Yusgiantoro, penetapan bendera mirip GAM sebagai bendera Aceh kemungkinan menjurus pada pembentukan wali negara. Purnomo pun setuju jika penggunaan bendera itu dipandang bertentangan dengan Peraturan Pemerintah Nomor 77 Tahun 2007 tentang Lambang Daerah. ${ }^{8}$ Oleh karena itu, untuk menyelesaikan permasalahan ini, Pemerintah kemudian berinisiatif untuk mengadakan pertemuan antara para penandatangan MoU Helsinki dengan Pemerintah Aceh guna membahas solusi apa yang akan diambil Pemerintah. ${ }^{9}$

\footnotetext{
${ }^{5}$ Lihat Pasal 246 ayat (2) UU No. 11 Tahun 2006 tentang Pemerintahan Aceh.

${ }^{6}$ Lihat Pasal 246 ayat (3) UU No. 11 Tahun 2006 tentang Pemerintahan Aceh.

${ }^{7}$ http://www.antaranews.com/berita/370292/f-peta-minta-presiden-batalkan-qanun-bendera-aceh, diakses tgl 22 April 2013.

${ }^{8}$ http://www.atjehcyber.net/2013/04/purnomo-sebut-ada-motif-lain-di-balik.html, diakses tgl. 22 April 2013.

${ }^{9}$ Pertemuan ini diadakan untuk mencari solusi atas gejolak yang timbul akibat keberadaan qanun bendera. Pertemuan ini dihadiri oleh gubernur NAD Zaini Abdullah, Wagub NAD Muzakir Manaf, Jusuf Kalla, Malik Machmud, Hasbi Abdullah, Hamid Awaluddin, Sofyan Djalil, dan IG Agung Wesaka Puja. http://www.merdeka.com/peristiwa/ tim-helsinky-bertemu-gubernur-aceh-bahas-bahas-ganun-bendera.html, diakses tgl 21 April 2013.
} 
Pertemuan Tahap Pertama antara Tim Pemerintah Aceh dengan Tim Kementerian Dalam Negeri membahas soal Bendera dan Lambang Aceh di Batam, Kepulauan Riau, Selasa, 7 Mei 2013 melahirkan lima kesepakatan. Wakil Ketua Komisi A DPRA, Nurzahri mengatakan ${ }^{10}$ lima butir kesepakatan tersebut yaitu, pertama, menyepakati pertemuan lanjutan di Makassar pada 16 Mei, Kedua, Menteri Dalam Negeri meminta Gubernur mengajukan surat meminta masa klarifikasi Qanun Nomor 3 Tahun 2013 tentang Bendera dan Lambang Aceh (60 hari sejak disahkan) agar dapat diperpanjang sampai 1 Juli. Ketiga, Pemerintah Pusat meminta Gubernur Aceh dan DPRA meninjau kembali agar ada perubahan sedikit Bendera dan Lambang Daerah Aceh. Keempat, seluruh peraturan turunan UUPA yang menjadi kewajiban pemerintah pusat seperti PP Migas, PP Kewenangan dan Perpres Pertanahan akan diselesaikan bersamaan setelah masalah Qanun Bendera dan Lambang Aceh. Kelima, terkait dengan apabila terjadi sengketa kewenangan antara Pemerintah Aceh dengan lembaga negara, seperti KPU dan Bawaslu dan sebagainya yang bertentangan dengan UUPA akan diselesaikan dengan difasilitasi oleh Menteri Dalam Negeri. Namun, perundingan lanjutan pada 23 Mei 2013, dicapai kesepakatan untuk kembali memperpanjang waktu pembahasan Qanun Nomor 3 Tahun 2013 tentang Lambang dan Bendera Aceh, menjadi 90 hari, kira-kira sampai bulan Juli, terhitung sejak 17 April 2013. Kemudian, Menteri Dalam Negeri Gamawan Fauzi mengatakan memperpanjang masa 'perundingan' penggunaan lambang dan simbol pada bendera daerah terkait Qanun Nomor 3 Tahun 2013 untuk kedua kalinya hingga 14 Agustus 2013 karena belum mendapatkan kesepakatan antara Pemerintah dan Pemda Aceh. ${ }^{11}$ Selain itu, Mendagri juga meminta masyarakat Aceh untuk tidak mengibarkan bendera GAM atau yang menyerupai itu karena (Qanun) itu belum sah secara hukum.

\section{Rumusan Masalah}

Adapun permasalahan dalam penelitian ini: pertama, apakah Pemerintah berwenang dalam melakukan pembatalan terhadap Qanun No. 3 Tahun 2013 tentang Bendera dan Lambang Aceh? Kedua, apa urgensi pengawasan preventif terhadap Qanun No. 3 Tahun 2013 tentang Bendera dan Lambang Aceh?

\footnotetext{
${ }^{10} \mathrm{http}: / /$ aceh.tribunnews.com/2013/05/08/alot-pertemuan-aceh-jakarta-di-batam, diakses tgl 26 juli 2013.

${ }^{11} \mathrm{http}: / /$ theglobejournal.com/Politik/mendagri-pemerintah-dan-masyarakat-aceh-jangan-kibarkan-benderabintang-bulan/index.php, diakses tgl 26 juli 2013.
} 


\section{Tujuan Penelitian}

Adapun tujuan penelitian ini adalah untuk mengetahui, pertama, kewenangan Pemerintah dalam pembatalan Qanun No. 3 Tahun 2013 tentang Bendera dan Lambang Aceh. Kedua, urgensi pengawasan preventif terhadap Qanun No. 3 Tahun 2013 tentang Bendera dan Lambang Aceh.

\section{Metode Penelitian}

Penelitian ini merupakan penelitian yang bersifat normatif. Bentuk penelitian ini adalah penelitian preskriptif, yaitu penelitian yang ditujukan untuk mendapatkan saran-saran mengenai apa yang harus dilakukan guna mengatasi masalah di masa yang akan datang. ${ }^{12}$ Pendekatan penelitian yang digunakan meliputi pendekatan perundang-undangan dan pendekatan konsep. Pendekatan perundang-undangan untuk menganalisis kewenangan pemerintah dalam pembatalan Qanun No. 3 Tahun 2013, sedangkan pendekatan konsep digunakan untuk memperoleh model pengawasan yang efektif terhadap perda atau qanun.

Jenis data yang digunakan adalah data sekunder. Sumber data sekunder yang digunakan mencakup bahan hukum primer, bahan hukum sekunder, dan bahan hukum tersier. Teknik pengumpulan data yang digunakan berupa studi pustaka melalui buku-buku literatur, peraturan perundang-undangan, serta pengumpulan data melalui media elektronik yang berhubungan dengan masalah yang diteliti.

Analisis yang digunakan dalam penelitian ini adalah deskriptif kualitatif, yaitu menganalisis bahan hukum yang ada untuk selanjutnya dikaji dan diinterpretasikan oleh peneliti untuk mendapatkan kesimpulan yang diharapkan.

\section{Hasil Penelitian dan Pembahasan}

\section{Konsekuensi Qanun sebagai Produk Hukum Daerah}

Lahirnya beragam produk hukum daerah pasca reformasi merupakan berkah kebijakan otonomi yang berlangsung sejak 1 Januari 2001. Aspirasi mengenai otonomi daerah dan desentralisasi muncul melalui sidang MPR 1998 yang

${ }^{12}$ Soerjono Soekanto, Pengantar Penelitian Hukum, Cetakan Ketiga, UI Press, Jakarta, 1986, hlm. 10. 
dituangkan dalam Ketetapan MPR No. XV/MPR/1998 tentang Penyelenggaraan Otonomi Daerah, Pengaturan, Pembagian, dan Pemanfaatan Sumber Daya Nasional yang Berkeadilan, serta Perimbangan Keuangan Pusat dan Daerah dalam Negara Kesatuan Republik Indonesia. TAP MRP ini menegaskan bahwa penyelenggaraan otonomi daerah: pengaturan, pembagian, dan pemanfaatan Sumber Daya Nasional yang berkeadilan, serta perimbangan keuangan pusat dan daerah dalam kerangka Negara Kesatuan Republik Indonesia dilaksanakan berdasarkan asas kerakyatan dan berkesinambungan yang diperkuat dengan pengawasan DPRD dan masyarakat. ${ }^{13}$ Untuk melaksanakan ketetapan tersebut maka dibentuklah UU No. 22 Tahun 1999 tentang Pemerintahan Daerah ${ }^{14}$ dan UU No. 25 Tahun 1999 tentang Perimbangan Keuangan antara Pemerintahan Pusat dan Daerah. ${ }^{15}$

Di samping melakukan Perubahan Kedua terhadap UUD 1945, pada Sidang Tahunan MPR RI 7-18 Agustus 2000 dikeluarkan Ketetapan MPR No. IV/MPR/ 2000 tentang Rekomendasi Kebijakan dalam Penyelenggaraan Otonomi Daerah, yang ditujukan kepada Pemerintah dan DPR agar ditindaklanjuti. Isi rekomendasi tersebut antara lain: ${ }^{16}$ a) keseluruhan peraturan pemerintah sebagai pelaksanaan dari kedua undang-undang tersebut agar diterbitkan selambat-lambatnya akhir desember tahun 2000; b) daerah yang sanggup melaksanakan otonomi secara penuh dapat segera memulai pelaksanaannya terhitung 1 Januari 2001 yang tercermin dalam anggaran pendapatan dan belanja negara dan anggaran pendapatan dan belanja daerah; c) daerah yang belum mempunyai kesanggupan melaksanakan otonomi secara penuh dapat memulai pelaksanaannya secara bertahap sesuai kemampuan yang dimilikinya; d) apabila keseluruhan peraturan pemerintah belum diterbitkan sampai dengan akhir Desember 2000, daerah yang mempunyai kesanggupan penuh untuk menyelenggarakan otonomi diberikan kesempatan untuk menerbitkan peraturan daerah yang mengatur pelaksanaannya. Jika peraturan pemerintah telah diterbitkan, peraturan daerah yang terkait harus disesuaikan dengan peraturan pemerintah tersebut. Rekomendasi MPR tersebut dimaksudkan

\footnotetext{
${ }^{13}$ Ni'matul Huda, Problematika Pembatalan Peraturan Daerah, FH UII Press, Yogyakarta, 2010, hlm. 5.

${ }^{14}$ UU ini diganti dengan UU No. 32 Tahun 2004 tentang Pemerintahan Daerah, kemudian karena adanya Putusan Mahkamah Konstitusi tentang calon perseorangan dalam Pemilukada, UU No. 32 Tahun 2004 direvisi dengan UU No.12 Tahun 2008 tentang Perubahan Kedua Atas UU No. 32 Tahun 2004 tentang Pemerintahan Daerah.

${ }^{15}$ UU ini diganti dengan UU No. 33 Tahun 2004 tentang Perimbangan Keuangan antara Pemerintahan Pusat dan Daerah.

${ }^{16}$ Ketetapan MPR RI Sidang Tahunan MPR RI 7-18 Agustus 2000, Eko Jaya, Jakarta, 2000, hlm. 53. Dikutip dalam Ni'matul Huda, "Pengawasan Pusat terhadap Daerah (Kajian terhadap Peraturan Daerah Bermasalah" dalam Jurnal Hukum, Vol. 10 No. 23, 2003, hlm. 29.
} 
untuk mengantisipasi jangan sampai terjadi kekosongan hukum di daerah setelah UU No. 22 Tahun 1999 melimpahkan semua urusan ke daerah dan menghindari terjadinya penyimpangan oleh Pemerintah Daerah dalam mengelola potensi dan kekayaan daerah, sehingga daerah diberi kesempatan untuk menerbitkan Perda. ${ }^{17}$

Atas terbukanya kesempatan untuk melaksanakan otonomi secara penuh, ternyata membawa sejumlah tuntutan pemisahan diri dari beberapa daerah, di antaranya adalah Papua dan Aceh. Sentralisasi yang selama Orde Baru membelenggu kedua daerah tersebut tidak dapat dibendung lebih lama lagi. Aceh ingin berdaulat dan mewacanakan referendum sebagai jalan tengah untuk menentukan masa depan Aceh. Namun, Pemerintah Pusat menolak dan akhirnya memberikan status Daerah Istimewa Aceh sebagai daerah otonomi khusus. Sebagai bentuk kekhususan pemerintahan Aceh, digunakan Qanun sebagai produk hukum daerah yang tercantum di dalam Pasal 1 ayat (8) UU No. 18 Tahun 2001 tentang Otonomi Khusus Bagi Provinsi Daerah Istimewa Aceh sebagai Provinsi Nanggroe Aceh Darussalam, bahwa Qanun Provinsi Nanggroe Aceh Darussalam adalah Peraturan Daerah sebagai pelaksanaan Undang-Undang di wilayah Provinsi Nanggroe Aceh Darussalam dalam rangka penyelenggaraan otonomi khusus. Sedangkan penjelasan UU No. 18 Tahun 2001 menyatakan Qanun Provinsi Nanggroe Aceh Darussalam adalah Peraturan Daerah Provinsi Nanggroe Aceh Darussalam, yang dapat mengenyampingkan peraturan perundang-undangan yang lain dengan mengikuti asas lex specialis derogaat lex generalis dan Mahkamah Agung berwenang melakukan uji materiil terhadap Qanun.

Istilah Qanun sudah digunakan sejak lama sekali dalam bahasa atau budaya Melayu. Kitab "Undang-Undang Melaka" yang disusun pada abad ke limabelas atau enambelas masehi telah menggunakan istilah ini. ${ }^{18}$ Menurut Liaw Yock Fang, istilah ini dalam budaya Melayu digunakan semakna dengan adat dan biasanya dipakai ketika ingin membedakan antara hukum yang tertera dalam adat dengan hukum yang tertera dalam kitab fiqh. ${ }^{19}$

Kanun (di Aceh disebut Qanun) menurut Kamus Umum Bahasa Indonesia adalah undang-undang, peraturan, kitab undang-undang. ${ }^{20}$ Sedangkan menurut

\footnotetext{
${ }^{17}$ Ni'matul Huda, Problematika Pembatalan Peraturan, Op. Cit., hlm. 8.

${ }^{18}$ Liaw Yock Fang, Undang-Undang Melaka, KITLV, Den Haag, 1976, hlm. 62. Dikutip dalam Al Yasa' Abubakar dan M. Daud Yoesoef, "Qanun sebagai Peraturan Pelaksanaan Otonomi Khusus di Provinsi Nanggroe Aceh Darussalam” dalam Jurnal Legislasi Indonesia, Vol. 1 No. 3 November 2004, Direktorat Jenderal Peraturan PerundangUndangan Departemen Hukum dan HAM, Jakarta, hlm. 20.

${ }^{19}$ Ibid.

${ }^{20}$ Kamus Umum Bahasa Indonesia, Edisi Ketiga, Balai Pustaka, Jakarta, 2003, hlm. 518.
} 
Kamus Al Munawwir, Qonun artinya asal, pokok, pangkal. ${ }^{21}$ Dalam literatur Melayu Aceh pun qanun sudah digunakan sejak lama, dan diartikan sebagai aturan yang berasal dari hukum Islam yang telah menjadi adat. Salah satu naskah tersebut berjudul Qanun Syara' Kerajaan Aceh yang ditulis oleh Teungku di Mulek pada $1257 \mathrm{H}$, atas perintah Sultan Alauddin Mansyur Syah yang wafat pada $1870 \mathrm{M}$. Naskah pendek ini berisi berbagai hal di bidang hukum tatanegara, pembagian kekuasaan, berbagai badan peradilan dan kewenangan mengadili, fungsi kepolisian dan kejaksaan serta aturan protokoler dalam berbagai upacara kenegaraan. ${ }^{22}$ Dapat disimpulkan dalam arti sempit, qanun merupakan suatu aturan yang dipertahankan dan diperlakukan oleh seorang Sultan dalam wilayah kekuasaannya yang bersumber pada hukum Islam, sedangkan dalam arti luas, qanun sama dengan istilah hukum atau adat. ${ }^{23}$

Ketentuan tentang Qanun terdapat di dalam Pasal 1 angka 12 Undang-Undang Pemerintahan Aceh No. 11 Tahun 2006, yaitu Qanun Aceh adalah peraturan perundang-undangan sejenis peraturan daerah provinsi yang mengatur penyelenggaraan pemerintahan dan kehidupan masyarakat Aceh. Pengertian Qanun tidak sama dengan Peraturan Daerah (Perda), karena isi dari Qanun haruslah berlandaskan pada asas keislaman atau tidak boleh bertentangan dengan syariat Islam. ${ }^{24}$ Namun, apabila melihat ketentuan dalam Penjelasan huruf $f$ dan $g$ UU No. 12 Tahun 2011, kedudukan Qanun dalam hierarkhi peraturan perundang-undangan termasuk dalam jenis Peraturan Daerah Provinsi dan Kabupaten/Kota. ${ }^{25}$ Oleh karena itu, pengawasan terhadap Qanun dilakukan oleh Pemerintah untuk mengharmonisasikan segala produk hukum daerah dengan peraturan perundangundangan yang lebih tinggi.

Dalam Pasal 12 Undang-Undang No. 10 Tahun 2004 menyatakan materi muatan Peraturan Daerah adalah seluruh materi muatan dalam rangka penyelenggaraan

${ }^{21}$ Kamus AlMunawwir Arab Indonesia Terlengkeap, Cetakan Keempat, Ahmad Warson Munawwir, Pustaka Progressif, Surabaya, 1997, hlm. 1165.

${ }^{22}$ Abdulah Sani Usman Basyah, Kanun Syarak Kerajaan Aceh pada Zaman Sultan Alauddin Mansur Syah: Tabkik. Kajian Bandingan dengan Bustanus Salatin, Fakultas Pengajian Islam, UKM, Kuala Lumpur, 2000, hlm. 17. Sebagaimana dikutip dalam dalam Al Yasa’ Abubakar dan M. Daud Yoesoef, “Qanun sebagai Peraturan.... Op. Cit., hlm. 20.

${ }^{23}$ Ibid., hlm. 21.

${ }^{24}$ Jum Anggriani, "Kedudukan Qanun dalam Sistem Pemerintahan Daerah dan Mekanisme Pengawasannya" artikel dalam Jurnal Hukum Ius Quia Iustum, No. 3 Vol. 18, Juli 2011, hlm. 327.

${ }^{25}$ Lihat Penjelasan huruf f UU No. 12 Tahun 2011: Termasuk dalam Peraturan Daerah Provinsi adalah Qanun yang berlaku di Provinsi Aceh dan Peraturan Daerah Khusus (Perdasus) serta Peraturan Daerah Provinsi (Perdasi) yang berlaku di Provinsi Papua danProvinsi Papua Barat. Huruf g: Termasuk dalam Peraturan Daerah Kabupaten/Kota adalah Qanun yang berlaku di Kabupaten/Kota di Provinsi Aceh. 
otonomi daerah dan tugas pembantuan, dan menampung kondisi khusus daerah serta penjabaran lebih lanjut peraturan perundang-undangan yang lebih tinggi. Pada pembuatan, pelaksanaan pengawasannya, Qanun dapat dibagi menjadi dua kategori, yaitu: ${ }^{26}$ Qanun umum dan Qanun khusus. Qanun umum berisi tentang ketentuanketentuan umum tentang penyelenggaraan pemerintahan seperti di bidang: pajak, retribusi, APBD, RUTR, dan semua urusan yang diberikan pusat kepada daerah diluar urusan atau kewenangan pusat, yang tidak boleh bertentangan dengan ajaran Islam. Sedangkan Qanun khusus berisi tentang aturan-aturan tentang penyelenggaraan kekhususan pemerintahan daerah NAD. Kriteria khusus yaitu: a) kehidupan beragama di NAD harus dilandasi ajaran Islam; b) kehidupan hukum adat haruslah berlandaskan ajaran Islam; c) penyelenggaraan pendidikan haruslah berdasarkan ajaran Islam; d) peran ulama sangat penting sebagai pemuka agama, karena itu ulama harus di ikut sertakan dalam pembuatan Qanun, agar kebijakan yang dibuat tidak bertentangan dengan ajaran Islam yang telah menjadi volkgeist atau jiwa bangsa dari masyarakat Aceh. Qanun No. 3 Tahun 2013 tidak termasuk di dalam Qanun umum maupun Qanun khusus karena materi yang diatur di dalamnya tidak berkaitan dengan pajak, retribusi, APBD, RUTR, serta tidak berisi tentang pelaksanaan syariat Islam.

Munculnya Qanun No. 3 Tahun 2013 tentang Bendera dan Lambang Aceh ini telah membuka kembali ruang perdebatan terhadap isu separatisme di Aceh. Sorotan utama dalam peristiwa ini adalah materi muatan yang terkandung dalam Qanun, mengenai pengaturan bendera daerah, di mana Qanun Aceh umumnya serupa dengan Perda bernuansa syariat Islam, yaitu:27 pertama, jenis Perda yang terkait dengan isu moralitas masyarakat secara umum; kedua, jenis Perda yang terkait dengan fashion dan mode pakaian; ketiga, jenis perda yang terkait dengan keterampilan beragama; dan keempat, jenis Perda yang terkait dengan pemungutan dana sosial dari masyarakat.

Perdebatan mengenai bendera Aceh sudah terlihat sejak pembahasan qanun ini berlangsung, dimana Yusril Izha Mahendra menilai usulan Pemerintah Provinsi Aceh terhadap Bendera dan Lambang Aceh yang menyerupai bendera GAM sebagai tindakan yang tak etis. Yusril beralasan, berdasarkan hasil pertemuan di Helsinki,

\footnotetext{
${ }^{26}$ Jum Anggriani, Kedudukan Qanun... Op. Cit., hlm. 328.

${ }^{27}$ Muntoha, "Otonomi Daerah dan Perkembangan "Peraturan-Peraturan Daerah Bernuansa Syariah", dalam Jurnal Hukum Ius Quia Iustum, Vol. 15 No. 2, April, 2008, hlm. 278.
} 
Finlandia pada 17 Desember 2012, Aceh boleh mempunyai lambang dan bendera Aceh yang mencerminkan kebudayaan Aceh, tapi tidak melambangkan kedaulatan Aceh. Yusril menyarankan untuk menggunakan lambang senjata khas Aceh yakni rencong untuk dijadikan lambang bendera Aceh. ${ }^{28}$ Karena telah mendapat pengesahan oleh DPRA, maka qanun bendera menjadi berlaku. Walaupun sudah disahkan, perdebatan terhadap substansi qanun bendera tetap ramai diperdebatkan banyak kalangan. Untuk menjembatani segala perdebatan ini, Menteri Dalam Negeri pun mengadakan pertemuan dengan Pemerintah Aceh guna membahas wacana evaluasi Perda pada 1 Mei 2013. Dirjen Otonomi Daerah menawarkan perpanjangan deadline pembahasan bendera sampai 1 Juli 2013. Persoalannya pun menjadi bertambah, apakah tidak ada batasan yang pasti dari pemerintah maupun daerah untuk melakukan klarifikasi Qanun?

Pengaturan pengawasan produk hukum daerah yang ada dalam UU No. 22 Tahun 1999 meniadakan pengawasan preventif. Padahal, pengawasan preventif diperlukan untuk mencegah disahkannya peraturan daerah yang bertentangan dengan peraturan yang lebih tinggi serta kepentingan umum. Pengawasan terhadap peraturan perundang-undangan semakin ditingkatkan pasca diberlakukannya UU No. 32 Tahun 2004. Produk hukum daerah perlu diawasi agar tidak menimbulkan kekacauan yang diakibatkan atas pemberlakuan perda tersebut. Pengawasan Pusat terhadap produk hukum daerah akan membawa konsekuensi bahwa Pusat berwenang untuk merevisi, membatalkan atau menangguhkan produk hukum daerah jika bertentangan dengan kepentingan umum dan bertentangan dengan peraturan perundang-undangan yang lebih tinggi.

Menurut Ridwan ${ }^{29}$, ada beberapa alasan pembenar penundaan dan pembatalan peraturan perundang-undangan dilakukan Pemerintah jika dilacak dari karakteristik penyelenggaraan pemerintahan daerah dalam negara kesatuan. Pertama, wewenang penyelenggaraan pemerintahan daerah muncul dari prinsip pemencaran wewenang pemerintahan, artinya dalam negara kesatuan pada dasarnya penyelenggaraan senya

${ }^{28}$ Dalam proses penyusunan qanun tersebut, Yusril bersama Jusuf Kalla termasuk dalam tim, mewakili Pemerintah untuk membahas penggunaan bendera GAM sebagai bendera Aceh. Dalam pertemuan itu banyak tokoh yang tidak sependapat. Tim pemerintah telah sepakat untuk menyarankan lambang rencong sebagai bendera aceh, karena rencong adalah senjata tradisional khas aceh dan dapat mewakili seluruh masyarakat aceh. Namun, ternyata Pemerintah Aceh memilih mengusulkan bendera GAM untuk dijadikan bendera Aceh. Sehingga terjadi perbedaan usulan antara Pemerintah Aceh dengan Pemerintah Pusat. http://www.voa-islam.com/news/indonesiana/2013/ 04/03/23884/di-aceh-merah-putih-diganti-bendera-gam-rakyat-tidak-peduli/, diakses tgl. 10 mei 2013

${ }^{29}$ Ridwan, “Dimensi Hukum Pengawasan terhadap Penyelenggaraan Otonomi Daerah”, dalam Jurnal Hukum No. 18 Vol. 8, 2001, hlm. 82. 
tugas-tugas pemerintahan negara menjadi tanggung jawab pemerintah pusat, namun untuk kepentingan efisiensi, efektifitas, dan tuntutan demokratisasi, tugas-tugas tersebut sebagian diserahkan pada satuan-satuan pemerintahan daerah, dan tanggungjawab secara keseluruhan tetap berada pada pemerintah pusat. Kedua, pembuatan peraturan perundang-undangan tingkat daerah hanya berkenaan dengan fungsi pemerintahan atau urusan rumah tangga daerah. Satuan pemerintahan daerah tidak diperkenankan membuat aturan di luar ruang lingkup kewenangannya ataupun aturan-aturan yang bersifat kenegaraan. Ketiga, kedudukan hukum daerah adalah subsistem dari negara kesatuan. Sebagai sub sistem, tugas-tugas dan kewenangan satuan pemerintahan daerah tidak dapat terlepas dari sistem dam kebijakan pemerintah dan negara. Keempat, pengawasan dimaksudkan untuk koordinasi dan integrasi tugas-tugas dan kebijaksanaan pemerintahan secara keseluruhan. Berdasarkan beberapa karakteristik inilah pengawasan terhadap peraturan perundangundangan tingkat rendah memiliki alasan pembenar. Semua perda bisa dilakukan pengawasan represif, sehingga pembatalan merupakan exclusive power Pemerintah Pusat. $^{30}$

Pengawasan dalam bahasa Inggris "control", yang berarti "to regulate or govern". ${ }^{31}$ Ditinjau dari hubungan Pusat dan Daerah, pengawasan merupakan "pengikat" kesatuan, agar bandul kebebasan berotonomi tidak bergerak begitu jauh sehingga mengurangi bahkan mengancam kesatuan (unitary). ${ }^{32}$ Tujuan utama dilakukannya pengawasan terhadap pemerintah menurut Paulus E. Lotulung ${ }^{33}$ adalah untuk menghindari terjadinya kekeliruan-kekeliruan, baik yang disengaja maupun yang tidak disengaja, sebagai suatu usaha preventif, atau juga untuk memperbaikinya apabila sudah terjadi kekeliruan itu, sebagai usaha represif. Dalam praktek, adanya kontrol itu sering dilihat sebagai sarana untuk mencegah timbulnya segala bentuk penyimpangan tugas pemerintahan dari apa yang telah digariskan. Di sinilah letak inti atau hakikat dari suatu pengawasan.

UU No. 32 Tahun 2004 melakukan koreksi terhadap UU No. 22 Tahun 1999 dengan menerapkan empat model pengawasan terhadap produk hukum daerah,

\footnotetext{
${ }^{30}$ Ridwan, Hukum Administrasi... Op. Cit., hlm. 155.

${ }^{31}$ Black's Law Dictionary, Ninth Edition, Bryan A. Garner (Ed), West Publishing, Dallas, 2009, hlm. 378.

${ }^{32}$ Bagir Manan, Hubungan Antara Pusat dan Daerah Menurut UUD 1945, Pustaka Sinar Harapan, Jakarta, 1994, hlm. 180

${ }^{33}$ Paulus E. Lotulung, Beberapa Sistem tentang Kontrol Segi Hukum terhadap Pemerintah, Edisi Kedua, Citra Aditya Bakti, Bandung, 1993, hlm. Xv.
} 
yaitu: ${ }^{34}$ (1) executive preview, yakni terhadap rancangan Peraturan Daerah yang mengatur pajak daerah, retribusi daerah, APBD, dan RUTR sebelum disahkan oleh kepala daerah terlebih dahulu dievaluasi oleh Menteri Dalam Negeri untuk Raperda Provinsi dan oleh Gubernur terhadap Raperda Kabupaten/Kota. ${ }^{35}$ (2) executive review (terbatas), yakni apabila hasil evaluasi Raperda tentang APBD dan rancangan Peraturan Gubernur/Peraturan Bupati/Walikota tentang penjabaran APBD dinyatakan bertentangan dengan peraturan perundang-undangan yang lebih tinggi tidak ditindaklanjuti oleh Gubernur/Bupati/Walikota bersama DPRD dan Gubernur/Bupati/Walikota tetap menetapkan raperda tersebut menjadi Perda dan Peraturan Gubernur/Bupati/Walikota, Mendagri untuk Provinsi dan oleh Gubernur untuk Kabupeten/Kota membatalkan Perda dan Peraturan Gubernur/Peraturan Bupati/Walikota tersebut. ${ }^{36}$ (3) pengawasan represif berupa pembatalan (executive review) terhadap semua Peraturan Daerah dilakukan oleh Presiden melalui Peraturan Presiden. (4) pengawasan preventif, yakni terhadap rancangan Peraturan Kepala Daerah tentang APBD baru dapat dilaksanakan setelah memperoleh pengesahan dari Menteri Dalam Negeri bagi Provinsi dan Gubernur bagi Kabupaten/Kota.

Di samping menerapkan empat model pengawasan oleh Pemerintah, UU No. 32 Tahun 2004 juga memberikan ruang kepada Pemerintah Daerah untuk mengajukan keberatan atas Peraturan Presiden yang membatalkan produk hukumnya melalui judicial review di Mahkamah Agung. ${ }^{37}$ Penerapan mekanisme tersebut juga dikaitkan dengan dasar pemikiran Indonesia adalah negara kesatuan (unitary state), sehingga dinilai rasional apabila pemerintahan pusat sebagai pemerintahan atasan diberi kewenangan untuk mengendalikan sistem hukum di lingkungan pemerintahan daerah. ${ }^{38}$ Yang dikendalikan atau dikontrol oleh Pemerintahan atasan itu antara lain adalah kontrol atas norma hukum yang ditetapkan oleh pemerintahan bawahan melalui apa yang dikenal sebagai "general norm control mechanism". ${ }^{39}$ Mekanisme kontrol norma umum inilah yang biasa disebut dengan sistem "abstract review" atau pengujian abstrak yang dapat dilakukan oleh lembaga eksekutif, lembaga legislatif,

\footnotetext{
${ }^{34}$ Ni'matul Huda, Problematika Pembatalan Peraturan., Op. Cit., hlm. 282.

${ }^{35}$ Lihat Pasal 185 ayat (1) UU No. 32 Tahun 2004

${ }^{36}$ Lihat Pasal 185 ayat (5) UU No. 32 Tahun 2004

${ }^{37}$ Lihat Pasal 24A ayat (1) UUD 1945, Lihat juga Pasal 145 ayat (5) UU No. 32 Tahun 2004 tentang Pemerintahan Daerah, Pasal 11 ayat (2) huruf b UU No. 4 Tahun 2004 tentang Kekuasaan Kehakiman, Pasal 31 UU No. 5 Tahun 2004 tentang Mahkamah Agung.

${ }^{38}$ Jimly Asshiddiqie, Perihal Undang-Undang, Rajawali Press, Jakarta, 2011, hlm. 67.

${ }^{39}$ Ibid., hlm. 74.
} 
ataupun oleh lembaga pengadilan. Jika "abstract review" itu dilakukan oleh lembaga eksekutif, dinamakan "executive review". Jika "abstract review" dilakukan oleh DPRD dan Pemerintah daerah yang menetapkan peraturan daerah itu sendiri, maka mekanisme peninjauan kembali semacam ini disebut "legislative review", sedangkan jika pengujian itu dilakukan oleh pengadilan, maka hal itu dinamakan "judicial review".$^{40}$ Pengujian oleh lembaga yudisial dalam judicial review adalah untuk menilai sesuai atau tidaknya satu peraturan perundang-undangan dengan peraturan perundang-undangan yang lebih tinggi secara hirarkis. Judicial review tidak bisa dioperasionalisasikan tanpa ada peraturan perundang-undangan yang tersusun secara hirarkhis. ${ }^{41}$

Berbeda halnya dengan pendapat Bagir Manan, dalam literatur yang ada terdapat beberapa tiga kategori besar pengujian peraturan perundang-undangan (dan perbuatan administrasi negara), yaitu: (1) pengujian oleh Badan peradilan (judicial review), (2) pengujian oleh badan yang sifatnya politik (political review), dan (3) pengujian oleh pejabat atau badan administrasi negara (administrative review). ${ }^{42}$ Dari pendapat di atas dapat disimpulkan bahwa pengujian peraturan perundangundangan dilakukan oleh Lembaga eksekutif tunggal; Lembaga Eksekutif dan Lembaga Legislatif; dan Badan Peradilan.

Sebagai konsekuensi dari dipilihnya bentuk negara kesatuan, maka Pemerintah Pusat dapat membatalkan Qanun yang dianggap bertentangan dengan peraturan perundang-undangan yang telah ditentukan, apapun bentuk Qanun itu, apakah berbentuk Qanun khusus ataupun berbentuk Qanun umum. ${ }^{43}$ Status sebagai daerah otonomi tidak menghilangkan pengawasan pemerintahan pusat terhadap produk hukum daerah demi menjaga harmonisasi dan hirarkhi peraturan perundangundangan.

Adanya dualisme kewenangan pembatalan peraturan daerah oleh lembaga eksekutif/pejabat atau badan administrasi dan lembaga peradilan merupakan perwujudan dari pembagian kekuasaan. Kontrol terhadap kesatuan Indonesia lebih bijak dilaksanakan secara kolektif, tanpa membedakan-bedakan lembaga yang berwenang menanganinya. Namun, yang menjadi ancaman adalah kecenderungan terjadinya kompromi politik yang pada akhirnya nanti akan menyandera lembaga

\footnotetext{
${ }^{40}$ Ibid.

${ }^{41}$ Moh. Mahfud MD., Membangun Politik Hukum, Menegakekan Konstitusi, LP3ES, Jakarta, 2007, hlm. 126-127.

${ }^{42}$ Ni'matul Huda, Negara Hukum, Demokrasi, dan Judicial Review, UII Press, Yogyakarta, 2005, hlm. 73. Lihat juga dalam Ni'matul Huda, Problematika Pembatalan .... Op. Cit., hlm. 73.

${ }^{43}$ Jum Anggriani, Kedudukan Qanun... Op. Cit., hlm. 332.
} 
peradilan sehingga berujung pada lahirnya keputusan yustisi yang menunjukkan keberpihakan pada kepentingan dari golongan tertentu. Lebih celaka lagi, jika justru mengancam disintegrasi bangsa hanya atas dasar kepentingan semu semata.

\section{Kewenangan Pengawasan dan Pembatalan terhadap Qanun Bendera}

Menurut Pasal 14 UU No. 12 Tahun 2011 tentang Pembentukan Peraturan Perundang-undangan yang berbunyi: " materi muatan Peraturan Daerah Provinsi dan Peraturan Daerah Kabupaten/Kota berisi materi muatan dalam rangka penyelenggaraan otonomi daerah dan tugas pembantuan serta menampung kondisi khusus daerah dan/atau penjabaran lebih lanjut Peraturan Perundang-undangan yang lebih tinggi." Oleh karena itu perda tidak boleh bertentangan dengan kepentingan umum, perda lain dan peraturan perundang-undangan yang lebih tinggi. Qanun adalah peraturan perundang-undangan yang ditetapkan dalam rangka penjabaran lanjut dari UU Pemerintahan Aceh No. 11 Tahun 2006.

Di dalam Pasal 239 ayat (1) UU No. 11 Tahun 2006 ditegaskan bahwa rancangan Qanun dapat berasal dari DPRA, Gubernur, dan DPRK, atau Bupati/Walikota. Ayat (2) menyatakan bahwa apabila dalam satu masa sidang, DPRA atau Gubernur dan DPRK atau Bupati/Walikota menyampaikan rancangan qanun mengenai materi yang sama, maka yang dibahas adalah rancangan qanun yang disampaikan oleh DPRA/ DPRK, sedangkan rancangan qanun yang disampaikan Gubernur dan Bupati/ Walikota digunakan sebagai bahan untuk dipersandingkan. Dalam Pasal 234 ayat (1) menyatakan: dalam hal rancangan qanun yang telah disetujui bersama oleh DPRA dan Gubernur atau DPRK dan bupati/walikota tidak disahkan oleh Gubernur atau bupati/walikota dalam waktu 30 (tiga puluh) hari sejak rancangan qanun disetujui, rancangan qanun tersebut sah menjadi qanun dan wajib diundangkan dengan menempatkannya dalam Lembaran Daerah Aceh atau Lembaran Daerah kabupaten/ kota. Terkait dengan kewenangan pembentukan bendera sebagai lambang daerah telah diakomodir di dalam Pasal 246 ayat (2) bahwa Pemerintah Aceh dapat menentukan dan menetapkan bendera daerah Aceh sebagai lambang yang mencerminkan keistimewaan dan kekhususan. Ayat (3) menyatakan bahwa bendera daerah Aceh sebagai lambang daerah bukan merupakan simbol kedaulatan dan tidak diberlakukan sebagai bendera kedaulatan di Aceh.

Menurut Jimly Asshsiddiqie, sebaiknya peraturan daerah sebagai produk legislatif di daerah hanya di "preview" oleh pemerintahan atasan apabila statusnya masih berupa 
rancangan peraturan daerah yang belum mengikat untuk umum. Jika peraturan daerah itu sudah mengikat untuk umum, maka yang mengujinya adalah lembaga peradilan sebagai pihak ketiga yang sama sekali tidak terlibat dalam proses pembentukan peraturan daerah yang bersangkutan. ${ }^{44}$ Hal ini sebagai konsekuensi dari dianutnya asas supremasi hukum, karena jika dibiarkan suatu peraturan daerah yang ditetapkan oleh para politikus yang duduk di lembaga eksekutif dan legislatif di tingkat pemerintahan bawahan, dibatalkan oleh para politikus yang duduk di lembaga eksekutif dan legislatif tingkat pemerintahan atasan, berarti peraturan daerah dibatalkan hanya atas dasar pertimbangan politik belaka. ${ }^{45}$ Seperti yang disampaikan oleh Mauro Cappelleti bahwa pengujian yang dilakukan oleh lembaga politik lebih bersifat preventif, yaitu pengujian dilakukan sebelum suatu peraturan daerah disahkan. ${ }^{46}$

Dalam Pasal 235 ayat (5) UU Pemerintahan Aceh menyatakan bahwa sebelum disetujui bersama antara Gubernur dan DPRA, serta bupati/walikota dan DPRK, Pemerintah mengevaluasi rancangan qanun tentang APBA dan Gubernur mengevaluasi rancangan APBK. Terkait hal-hal yang berada di luar APBA dan APBK, Pemerintah melakukan pengawasan represif. Hal ini menunjukkan bahwa adanya pengawasan preventif oleh Pemerintah terhadap Qanun hanya terbatas mengenai qanun yang berisi tentang APBA, APBK, pajak, retribusi, dan RUTR. Pengaturan yang seperti ini tidak ideal untuk diterapkan bagi daerah yang berstatus otonomi khusus seperti Aceh. Pembatalan Qanun oleh Pemerintah hanya berdasarkan pertimbangan politik dan teknis mengenai pengaturan keuangan daerah dan tata ruang, padahal produk hukum daerah yang lebih strategis dan bernuansa "otonomi khusus" seringkali mengundang kontroversi yang menuai pro dan kontra di tengah masyarakat di daerah. Sehingga jika Pemerintah benar-benar serius memberikan status otonomi khusus pada daerah yang berhak menerimanya, model pengawasan terhadap produk hukum daerah pun lebih ketat dan jelas dasar hukumnya. Pengawasan preventif diperlukan sebagai sarana kontrol sebagaimana yang dikemukakan oleh Newman, "control is assurance that the performance conform to plan". Pengawasan untuk menjamin agar pelaksanaan sesuai dengan perencanaan. ${ }^{47}$

\footnotetext{
${ }^{44}$ Jimly Assiddiqie, Perihal Undang-Undang... Op. Cit., hlm. 75.

${ }^{45}$ Ibid.

${ }^{46}$ Sri Soemantri M, Hak Uji Material di Indonesia, Cetakan Ketiga, Alumni, Bandung, 1982, hlm. 17

${ }^{47}$ Victor Jusuf Sedubun, "Pengawasan Preventif sebagai Bentuk Pengujian Peraturan Daerah", dalam Jurnal Konstitusi, MK kerjasama Pusat Kajian Konstitusi Universitas Udayana,Vol. I No. 1, 2012, hlm. 161.
} 
Pengawasan preventif terhadap qanun yang materi muatannya mengatur selain tentang APBA, APBK, pajak, retribusi, dan RUTR seharusnya juga dilakukan oleh Pemerintah. Menurut Thorbecke, terdapat 3 tujuan pengawasan preventif, yaitu: a) mempertahankan undang-undang atau kepentingan negara; b) mempertahankan kepentingan daerah/provinsi lain karena peraturan yang bersangkutan dapat mengenai pihak ketiga; c) mempertahankan kepentingan provinsi yang bersangkutan sendiri dan kepentingan atau hak bagian-bagiannya, Gemeente dan penduduk yang tidak diperhatikan oleh peraturan yang dibuat secara sepihak, salah dan bersifat memihak. ${ }^{48} \mathrm{Di}$ antara beberapa bentuk pengawasan preventif ini yang terpenting adalah pengesahan sebagai hak placet (recht van placet), yakni hak yang diberikan kepada organ pemerintahan yang lebih tinggi untuk membatalkan atau mengukuhkan suatu keputusan atau peraturan pejabat pemerintahan yang lebih rendah tingkatannya sebelum peraturan atau keputusan itu diberlakukan atau mempunyai kekuatan hukum mengikat. ${ }^{49}$ Jika pemerintah melakukan pengawasan preventif, berarti pemerintah juga berwenang untuk melakukan pengawasan represif.

Seperti telah diketahui bahwa sistem Eropa Kontinental yang berlaku di Indonesia masih memegang teguh asas legalitas dalam kegiatan penyelenggaraan negara. Kemudian timbul pertanyaan, apakah berarti bahwa yang berhak menyelesaikan perkara qanun bendera dan lambang Aceh adalah Mahkamah Agung? Kewenangan Mahkamah Agung (MA) untuk menguji Perda terdapat dalam Pasal 24A ayat (1) UUD 1945 yang menyatakan bahwa Mahkamah Agung berwenang mengadili pada tingkat kasasi, menguji peraturan perundang-undangan di bawah undang-undang terhadap undang-undang, dan mempunyai wewenang lainnya yang diberikan oleh undang-undang. Pasal 235 ayat (4) UU No. 11 Tahun 2006 yang menyatakan: Qanun yang mengatur tentang pelaksanaan syari'at Islam hanya dapat dibatalkan melalui uji materiil oleh Mahkamah Agung (MA). Pasal ini memberikan kewenangan kepada MA untuk membatalkan Qanun yang berisi pelaksanaan syariat Islam.

Terlihat dari dari ketentuan di atas bahwa Pemerintah Pusat tidak dapat membatalkan pemberlakuan suatu Qanun yang bersifat khusus yang berisi pelaksanaan syariat Islam. Hal ini menimbulkan permasalahan tersendiri, karena konsekuensi dari suatu pengawasan adalah berupa revisi, penangguhan atau

\footnotetext{
${ }^{48}$ Bagir Manan, Hubungan Pusat... Op. Cit., hlm. 108-109.

${ }^{49}$ Ridwan, Hukum Administrasi... Op. Cit., hlm. 137.
} 
pembatalan suatu Qanun. Pengawasan Pusat terhadap Qanun mutlak diperlukan, agar penyelenggaraan pemerintahan di Aceh dapat berjalan dengan baik dan lancar, oleh karenanya diperlukan perubahan terhadap Pasal 235 ayat (4) UU No. 11 Tahun 2006. Mekanisme pengawasan represif dianggap terbaik bagi Pusat untuk mengawasi Qanun khusus. ${ }^{50}$

Adanya dualisme kewenangan pembatalan Qanun oleh Pemerintah Pusat dan Mahkamah Agung sangatlah tidak efektif. Qanun sebagai produk legislasi daerah seharusnya sebelum disahkan Pemerintah Aceh dan DPRA terlebih dahulu diklarifikasi oleh Pemerintah Pusat. Pasal 234 ayat (1) UU No. 11 Tahun 2006 menyatakan dalam hal rancangan rancangan Qanun yang telah disetujui bersama oleh DPRA dan Gubernur atau DPRK dan bupati/walikota tidak disahkan oleh Gubernur atau bupati/walikota dalam waktu 30 (tiga puluh) hari sejak rancangan Qanun disetujui, rancangan Qanun tersebut sah menjadi Qanun dan wajib diundangkan dengan menempatkannya dalam Lembaran Daerah Aceh atau Lembaran Daerah kabupaten/kota. Pasal ini tidak mengatur pengawasan preventif oleh Pemerintah Pusat. Evaluasi rancangan Qanun hanya terbatas pada Qanun yang menyangkut Qanun APBA dan APBK. Pengelolaan urusan pemerintahan daerah hendaknya juga menjadi objek pengawasan pemerintah Pusat. Mekanisme pengawasan preventif terhadap Raperda juga semestinya berlaku bagi daerah yang berstatus otonomi khusus, dalam hal ini bukan hanya Aceh, tetapi juga Papua.

Bagir Manan menyatakan bahwa kemandirian dalam berotonomi tidak berarti daerah dapat membuat peraturan perundang-undangan atau keputusan yang terlepas dari sistem perundang-undangan secara nasional. Peraturan perundangundangan tingkat daerah merupakan bagian yang tidak terpisahkan dari kesatuan sistem perundang-undangan secara nasional. Karena itu tidak boleh ada peraturan perundang-undangan tingkat daerah yang bertentangan dengan peraturan perundang-undangan yang lebih tinggi tingkatnya atau kepentingan umum. ${ }^{51}$ Kepentingan umum yang harus diperhatikan, bukan saja kepentingan rakyat banyak daerah yang bersangkutan, tetapi kepentingan daerah lain dan kepentingan seluruh rakyat Indonesia. ${ }^{52}$ Sebagai perwujudan desentralisasi, peraturan perundangundangan tingkat daerah merupakan pengejawantahan beberapa sendi

\footnotetext{
${ }^{50}$ Jum Anggriani, Kedudukan Qanun... Op. Cit., hlm. 331.

${ }^{51}$ Bagir Manan, Sistem dan Teknik Pembuatan Peraturan Perundang-undangan Tingkat Daerah, Pusat Penerbitan Universitas LPPM UNISBA, Bandung, 1995, hlm. 9.

${ }^{52}$ Ibid.
} 
ketatanegaraan yang berdasarkan Pancasila dan UUD 1945, seperti: ${ }^{53}$ (1) sendi negara berdasarkan atas hukum dan negara berkonstitusi. (2) sendi kerakyatan yang dipimpin oleh hikmat kebijaksanaan dalam permusyawaratan/perwakilan. (3) sendi kesejahteraan umum dan keadilan sosial bagi seluruh rakyat. Sudah seharusnya pemerintah merevisi model pembuatan kebijakan yang mengintegrasikan beragam kepentingan, baik daerah yang bersangkutan, daerah lain, juga menyangkut kepentingan NKRI yang oleh Djohermansyah Djohan dinamai “model pembuatan kebijakan otonomi daerah yang progresif-kreatif". ${ }^{54}$

Oleh karena itu, akan lebih tepat jika kewenangan preventif tetap ada pada pemerintah pusat. Pengesahan yang melekat pada pengawasan preventif senantiasa diperlukan karena: ${ }^{55}$ a) pengesahan merupakan perwujudan pengawasan (toezich). Pengawasan itu sendiri merupakan salah satu sendi sistem penyelenggaraan pemerintahan berotonomi. Tiada sistem penyelenggaraan pemerintahan berotonomi tanpa pengawasan; b) Pengesahan merupakan perwujudan hak "placet", yaitu hak yang ada pada satuan atau pejabat yang lebih tinggi tingkatannya untuk mencegah atau mengukuhkan agar suatu keputusan satuan yang lebih rendah tingkatannya mempunyai keputusan mengikat; c) pengesahan dapat juga dipandang sebagai tindak lanjut dalam pembuatan peraturan daerah atau keputusan lain yang memerlukan pengesahan; d) pengesahan merupakan cara melakukan pemeriksaan (checking), dalam rangka mempertahankan peraturan perundang-undangan yang lebih tinggi tingkatannya, kepentingan pemerintahan daerah lain yang mungkin terkena (baik langsung maupun tidak langsung) dan lain sebagainya. Pemerintah harus terus menerus melakukan supervisi kepada daerah dan melakukan kerjasama dengan berbagai pihak dalam bentuk pembekalan atau pendampingan kepada daerah dalam pembentukan produk hukum daerah secara intensif, agar kesalahan dalam pembuatan produk hukum daerah tidak terus menerus berulang. Demikian pula, pemerintah harus konsisten melaksanakan berbagai peraturan yang sudah diamanatkan oleh UU Pemerintahan daerah. ${ }^{56}$

\footnotetext{
${ }^{53}$ Ibid., hlm. 9.

${ }^{54}$ Djohermansyah Djohan, “Sejarah Kebijakan Otonomi Khusus” dalam Pasang Surut Otonomi Daerab Sketsa Perjalanan 100 Tahun, Soetandyo Wignosubroto, dkk, Institut for Local Development, Yayasan Tifa, Jakarta, 2005, hlm. 616.

${ }^{55}$ Ridwan, Hukum Administrasi...., Op. Cit., hlm. 137.

${ }^{56}$ Ni'matul Huda, Problematika Pembatalan .... Op. Cit., hlm. 337.
} 


\section{Urgensi Pengawasan Preventif}

Pengawasan preventif sudah pernah diatur dalam UU No. 1 Tahun 1957 tentang Pokok-Pokok Pemerintahan Daerah. Dalam penjelasan umum UU No. 1 Tahun 1957 dinyatakan bahwa pengawasan preventif hanya diharuskan bagi beberapa keputusan tertentu saja, dalam mana tersangkut kepentingan-kepentingan besar atau kemungkinan timbulnya kegelisahan-kegelisahan dan gangguan-gangguan dalam hal penyelenggaraan kepentingan umum oleh pemerintahan daerah sehingga dengan demikian kemungkinan datangnya kerugian atas kepentingan-kepentingan itu dapat dicegah sebelumnya. Berbeda dengan undang-undang sebelumnya yang hanya mengatur mengenai daerah otonom (pemerintahan otonom), UU No. 5 Tahun 1974 mengatur juga pemerintahan dekonsentrasi (yang disebut wilayah administratif). Pengawasan preventif menurut UU No. 5 Tahun 1974 mengandung prinsip bahwa Peraturan Daerah (Perda) dan Keputusan Kepala Daerah mengenai pokok tertentu baru berlaku sesudah ada pengesahan pejabat yang berwenang. Jadi, pengawasan preventif dilakukan sesudah Peraturan Daerah atau Keputusan Kepala Daerah ditetapkan, tetapi sebelum Peraturan dan Keputusan itu berlaku. Bagi Perda khususnya, pengawasan preventif dilakukan sesudah perda itu ditetapkan oleh Kepala Daerah itu dengan persetujuan DPRD tetapi sebelum perda itu diundangkan.

Menurut UU No. 32 Tahun 2004, Menteri Dalam Negeri melakukan pengawasan terhadap Perda dan Peraturan Kepala Daerah. ${ }^{57}$ Ada 2 bentuk pengawasan yang dapat dilakukan, yaitu: klarifikasi dan evaluasi. Pengawasan terhadap peraturan daerah dan peraturan kepala daerah yang sudah di sahkan, disebut klarifikasi, sedangkan penilaian dan pengujian terhadap rancangan perda dan peraturan kepala daerah dinamakan evaluasi. ${ }^{58}$ Dalam praktik berotonomi, mekanisme kontrol tidak bisa dilepaskan begitu saja. Oleh karena itu, pengawasan yang dilakukan pemerintah berupa pengawasan preventif akan mendatangkan banyak manfaat; pertama, mencegah muatan Qanun yang bertentangan dengan peraturan perundang-undangan di atasnya. Kedua, pengawasan preventif dapat meredam upaya separatisme yang dituangkan dalam produk hukum daerah. Ketiga, dalam menjaga martabat masing-masing pihak, baik pemerintah pusat maupun

\footnotetext{
${ }^{57}$ Lihat lebih lanjut dalam Pasal 2 ayat (1) Peraturan Menteri Dalam Negeri No. 53 Tahun 2007 tentang Pengawasan Peraturan Daerah dan Peraturan Kepala Daerah.

${ }^{58}$ Lihat dalam Pasal 1 ayat (4), (5) dan (6) Peraturan Menteri Dalam Negeri No. 53 Tahun 2007 tentang Pengawasan Peraturan Daerah dan Peraturan Kepala Daerah.
} 
pemerintah daerah, keduanya harus saling menghormati dan menjadikan kepentingan bangsa sebagai kepentingan yang utama. Pengawasan represif berupa pembatalan perda/Qanun sebagai alternatif terakhir dilakukan oleh lembaga yudisial untuk menjamin supremasi hukum di Indonesia. Jika pembatalan Qanun dilakukan oleh pejabat yang berwenang, dikhawatirkan akan terjadi penyalahgunaan wewenang, dimana pembatalan dipergunakan tanpa dasar alasan yang jelas, yang dijadikan sebagai "senjata yang ampuh" untuk mematikan otonomi daerah. Jangan sampai pembatalan disalahgunakan menjadi turut mengatur dan memerintah. Namun, menyerahkan pengaturan otonomi daerah kepada pemerintah tanpa kontrol sama halnya dengan menggagalkan otonomi daerah itu sendiri..$^{59}$

Menurut Yance Arizona, ${ }^{60}$ proses evaluasi Perda oleh Pemerintah Pusat memakan waktu yang lama, meskipun UU Pemerintah Daerah menyatakan bahwa pembatalan perda ditetapkan dengan Peraturan Presiden paling lama 60 (enam puluh) hari sejak diterimanya perda oleh pemerintah Pusat, evaluasi perda oleh Pemerintah Pusat tetap memakan waktu yang lama. Lamanya proses evaluasi perda oleh pemerintah pusat berimplikasi pada terabainya kepastian hukum penerapan perda di daerah. Hal ini terlihat pada evaluasi Qanun Aceh tentang bendera dan lambang Aceh telah dilakukan klarifikasi oleh Menteri Dalam Negeri. Sejak ditetapkan pada 25 Maret 2013, Qanun Bendera telah mengalami perpanjangan sebanyak 3 kali, terakhir pada 15 November 2013, dan belum jelas hasilnya. Padahal, secara normatif pemerintah membatalkan perda paling lambat 60 hari sejak Perda diterima oleh Pemerintah. ${ }^{61}$ Meminjam istilah Robert Endi Jaweng, proses pengujian perda yang membutuhkan waktu 60 hari dan berlaku secara otomatis, merupakan kebijakan yang ideal secara politik tetapi sulit dijalankan dan berpotensi gagal. ${ }^{62}$ Panjangnya masa pertimbangan Qanun ini telah menimbulkan kekisruhan yang berujung pada suasana ketidakpastian hukum di Provinsi NAD dan memunculkan sentimen negatif terhadap Pemerintah Pusat yang lamban dalam memeriksa Peraturan Daerah. Secara normatif, evaluasi terhadap rancangan peraturan daerah

\footnotetext{
${ }^{50} \mathrm{http}$ ///vancearizona.files.wordpress.com/2008/07/disparitas-pengujian-peraturan-daerah.pdf, diakses tgl 4 Juli 2014, hlm. 9

${ }^{60} \mathrm{http://yancearizona.files.wordpress.com/2008/07/disparitas-pengujian-peraturan-daerah.pdf,} \mathrm{diakses} \mathrm{tgl}$ 4 Juli 2014, hlm. 6.

${ }^{61}$ Lihat Pasal 38 ayat (1) PP No. 79 Tahun 2005 tentang Pedoman Pembinaan dan Pengawasan Penyelenggaraan Pemerintahan Daerah.

${ }^{62}$ Robert Endi Jaweng, Mekanisme Baru Pengawasan Perda PDRD, http://www.kppod.org/datapdf/brief/ KPPOD Brief05.pdf, diakses tanggal 1 juli 2014.
} 
hanya terbatas pada raperda yang bermuatan APBD, pajak dan retribusi serta tata ruang, membatasi kontrol pemerintah terhadap rancangan perda yang mengatur hal lain seperti rancangan Perda bendera, wali nanggroe atau produk hukum daerah lain yang berstatus otonomi khusus. Jika Pemerintah terlebih dahulu mengevaluasi rancangan Qanun ini, maka setidaknya ketegangan dan suasana ketidakpastian hukum di Aceh tidak perlu terjadi. Sebaiknya, untuk mencegah terjadinya ketidakpastian hukum di berbagai daerah akibat adanya peraturan daerah atau Qanun yang sudah berlaku, yang ternyata dalam prakteknya bertentangan dengan peraturan perundang-undangan di atasnya atau bertentangan dengan kepentingan umum, dilakukan perubahan terhadap Pasal 185 UU No. 32 Tahun 2004, dengan menambahkan kewajiban evaluasi rancangan perda bagi daerah berstatus otonomi khusus, misalnya perda atau Qanun tentang bendera dan lambang daerah, Wali Nanggroe, dan perda tentang perizinan. Perubahan Pasal ini dalam rangka menghidupkan kembali pengawasan preventif terhadap peraturan daerah untuk menjegal lolosnya "rancangan perda nakal" di berbagai wilayah daerah otonomi khusus demi menjaga keutuhan NKRI. Kewenangan preventif ini diperlukan untuk mengakomodir perkembangan daerah otonomi khusus di Indonesia kaitannya dengan pengawasan produk pemerintahan daerah otonomi khusus.

Sikap pemerintah hingga saat ini belum jelas terhadap eksistensi Qanun bendera tersebut, apakah Pemerintah akan membatalkannya atau menunggu hasil revisi dari Pemerintah Aceh. Kalaupun nantinya Pemerintah akan membatalkan Qanun bendera tersebut, Pemerintah sudah tidak memiliki kewenangan karena sudah lewat waktu atau daluwarsa di waktu yang seharusnya sebagaimana ditentukan dalam UU No. 32 Tahun 2004. Berlarut-larutnya Pemerintah bersikap terhadap Qanun No. 3 Tahun 2013 tentang Bendera dan Lambang Aceh justru menimbulkan ketidakpastian terhadap status hukum Qanun tersebut. 'Kegamangan' sikap Pemerintah tersebut justru menguntungkan Pemerintah Aceh karena batas waktu kewenangan Pemerintah Pusat untuk membatalkan sudah lampau waktu sehingga Qanun No. 3 Tahun 2013 tentang Bendera dan Lambang Aceh sudah sah berlaku. Inilah resiko yang harus diterima oleh Pemerintah jika tidak berani bersikap tegas terhadap daerah dalam melaksanakan pengawasan, baik pengawasan terhadap produk hukumnya maupun pengawasan terhadap aktivitas politiknya yang dapat mengancam NKRI.

Adanya dualisme pembatalan Qanun (oleh Pemerintah dan Mahkamah Agung) berpotensi menimbulkan benturan wewenang antara pemerintah pusat dan 
pemerintah daerah, serta ketidakjelasan pengaturan pembatalan Qanun akan menyebabkan perbedaan penafsiran akan semakin meresahkan masyarakat. Sebaiknya Pemerintah mulai menghidupkan kembali gagasan untuk melakukan pengawasan preventif terhadap Qanun. Serta dilakukan Perubahan terhadap Pasal 185 UU Pemerintahan Daerah yang berkaitan dengan evaluasi raperda, yaitu menambah kewenangan Pemerintah Pusat untuk melakukan pengawasan preventif terhadap rancangan peraturan daerah otonomi khusus.

Pemerintah tidak boleh membatalkan Perda hanya karena materi muatannya bertentangan dengan peraturan yang diatasnya. Kekhasan dan kondisi khusus daerah perlu diakomodir kepentingannya dalam peraturan perundangan, untuk menjaga keragaman dalam sistem pemerintahan Indonesia. Apalagi Pasal 18 UUD 1945 dengan tegas memberikan penghormatan bagi daerah yang bersifat khusus dan bersifat istimewa untuk mengatur sendiri model pemerintahannya. Ketidakpastian sikap pemerintah jelas bertolak belakang dengan semangat otonomi daerah yang terkandung dalam UUD 1945.

\section{Penutup}

Berdasarkan pada permasalahan di atas, dapat ditarik kesimpulan sebagai berikut. Pertama, Pemerintah sudah tidak berwenang untuk membatalkan Qanun bendera dan lambang Aceh karena masa waktu pembahasan sudah daluwarsa. Pemerintah telah melanggar ketentuan Pasal 145 UU No. 32 Tahun 2004 jo UU No. 12 Tahun 2008 tentang Pemerintahan Daerah karena proses pembahasan Qanun bendera sudah melewati batas 60 hari sejak diterimanya perda oleh Pemerintah.

Kedua, urgensi pengawasan preventif terhadap Qanun No. 3 Tahun 2013 tentang Bendera dan Lambang Aceh sangat diperlukan oleh Pemerintah untuk menjamin supremasi hukum dan memelihara persatuan NKRI.

\section{Daftar Pustaka}

Anggriani, Jum, "Kedudukan Qanun dalam Sistem Pemerintahan Daerah dan Mekanisme Pengawasannya" artikel dalam Jurnal Hukum Ius Quia Iustum, No. 3 Vol. 18, Juli 2011.

Asshiddiqie, Jimly, Perihal Undang-Undang, Rajawali Press, Jakarta, 2011. 
Black's Law Dictionary, Ninth Edition, Bryan A. Garner (Ed), West Publishing, Dallas, 2009.

Huda, Ni' matul, Negara Hukum, Demokrasi, dan Judicial Review, UII Press, Yogyakarta, 2005. , Problematika Pembatalan Peraturan Daerah, FH UII Press, Yogyakarta, 2010.

Kamus Umum Bahasa Indonesia, Edisi Ketiga, Balai Pustaka, Jakarta, 2003.

Mahfud MD., Moh., Membangun Politik Hukum, Menegakkan Konstitusi, LP3ES, Jakarta, 2007.

Manan, Bagir, Hubungan Antara Pusat dan Daerah Menurut UUD 1945, Pustaka Sinar Harapan, Jakarta, 1994. , Menyongsong Fajar Otonomi Daerah, PSH FH UII, Yogyakarta, 2001.

Sistem dan Teknik Pembuatan Peraturan Perundang-undangan Tingkat Daerah, Pusat Penerbitan Universitas LPPM UNISBA, Bandung, 1995.

Muntoha, "Otonomi Daerah dan Perkembangan "Peraturan-Peraturan Daerah Bernuansa Syariah", dalam Jurnal Hukum Ius Quia Iustum, Vol. 15 No.2, April, 2008.

Nurhasim, Moch., Konflik dan Integrasi Politik GAM: Kajian tentang Konsensus Normatif antara RI-GAM dalam Perundingan Helsinki, Pustaka Pelajar dan PSP LIPI, Yogyakarta, 2008.

Ridwan, Hukum Administrasi di Daerah, FH UII Press, Yogyakarta, 2009.

Soejito, Irawan, Pengawasan terhadap Peraturan Daerah dan Keputusan Kepala Daerah, Bina Aksara, Jakarta, 1983.

Soekanto, Soerjono, Pengantar Penelitian Hukum, Cetakan Ketiga, UI Press, Jakarta, 1986.

Soemantri M, Sri, Hak Uji Material di Indonesia, Cetakan Ketiga, Alumni, Bandung, 1982.

Wignosubroto, Soetandyo, dkk., Pasang Surut Otonomi Daerah Sketsa Perjalanan 100 Tahun, Institut for Local Development, Yayasan Tifa, Jakarta, 2005

UUD 1945

UU No. 12 Tahun 2011 tentang Pembentukan Peraturan Perundang-Undangan.

UU No. 22 Tahun 1999 tentang Pemerintahan Daerah

UU No. 32 Tahun 2004 tentang Pemerintahan Daerah

UU No. 4 Tahun 2004 tentang Kekuasaan Kehakiman

UU No. 5 Tahun 2004 tentang Mahkamah Agung.

UU No. 11 Tahun 2006 tentang Pemerintahan Aceh.

http://www.atjehcyber.net/2013/04/purnomo-sebut-ada-motif-lain-di-balik.html, diakses tgl. 22 April 2013. 
http://regional.kompas.com/read/2013/03/25/20062356/ Bendera.GAM.Resmi.Berlaku.di.Aceh, diakses 23 April 2013.

http://www.antaranews.com/berita/370292/f-peta-minta-presiden-batalkanganun-bendera-aceh, diakses tgl 22 April 2013.

http://www.atjehcyber.net/2013/04/purnomo-sebut-ada-motif-lain-di-balik.html, diakses tgl. 22 April 2013.

http://www.merdeka.com/peristiwa/tim-helsinky-bertemu-gubernur-aceh-bahasbahas-qanun-bendera.html, diakses tgl 21 April 2013.

http://www.tempo.co/read/news/2013/05/01/078477022/Ketua-MK-QanunBendera-Aceh-Tak-Langgar-UUD, diakses tgl. 30 April 2013.

http://polri-bali.blogspot.com/2008/05/qanun-sebagai-peraturanpelaksanaan.html, diakses tgl 10 Mei 2013. 